Original Article

\title{
An antimicrobial activity of oil extracted from Saara hardwickii
}

\author{
Atividade antimicrobiana do óleo extraído de Saara hardwickii
}

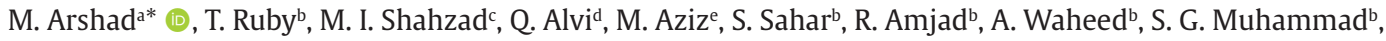 \\ A. Shaheen ${ }^{\mathrm{b}}$ and S. Ahmed ${ }^{\mathrm{f}}$ \\ ${ }^{a}$ Government College University Fasialabad Sahiwal campus, Sahiwal, Pakistan \\ 'The Islamia University of Bahawalpur, Department of Zoology, Bahawalpur, Pakistan \\ 'The Islamia University of Bahawalpur, Department of Biochemistry, Institute of Biochemistry, Biotechnology and Bioinformatics, Bahawalpur, \\ Pakistan \\ 'Taylor's University, Faculty of Health and Medical Sciences, School of Biosciences, Kualalampur, Selangor, Malaysia \\ eBahauddin Zakariya University, Department of Microbiology and Genetics, Multan, Pakistan \\ fBahauddin Zakariya University, Institute of Pure and Applied Biology, Zoology Division, Multan, Pakistan
}

\begin{abstract}
Present research work represents antiviral and antibacterial value of body fat of Saara hardwickii commonly called as spiny tailed lizard. Oil was extracted from body fats located in the ventral region of this animal using hydrocarbons e.g., n-hexane, methanol, butanol and ethyl acetate as a solvent. The antibacterial activity of lizard oil was tested against standard as well as multi-resistant lines of Escherichia coli, Styphalococcus aureus, Pseudomonas aeruginosa and Proteus vulgaris alone and with antibiotic ampicillin. For antibacterial potential, Ethyl acetate and Butanol solvent extract showed best zone of inhibition $(7 \mathrm{~mm})$ with $P$. aeruginosa and S. aureus respectively. For antiviral potential, Butanol and Methanol extract showed best HA (Hemagglutination) titer of 04 with NDV and IBV viral strain respectively. It is concluded that lizard oil has antimicrobial potential against different pathogens strains (virus, bacteria).
\end{abstract}

Keywords: Saara hardwickii, hemagglutination, antibacterial, antiviral, zone of inhibition, zootherapeutic.

\begin{abstract}
Resumo
O presente trabalho de pesquisa apresenta a importância antiviral e antibacteriana da gordura corporal de Saara hardwickii, comumente chamado de lagarto de cauda espinhosa. O óleo foi extraído de gorduras corporais localizadas na região ventral desse animal usando hidrocarbonetos, por exemplo, n-hexano, metanol, butanol e acetato de etila, como solvente. A atividade antibacteriana do óleo do lagarto foi testada em linhagens padrão e multirresistentes de Escherichia coli, Staphylococcus aureus, Pseudomonas aeruginosa e Proteus vulgaris, de forma isolada e com antibiótico ampicilina. Para o potencial antibacteriano, acetato de etila e extrato de butanol apresentaram melhor zona de inibição $(7 \mathrm{~mm})$ com $P$. aeruginosa e $S$. aureus, respectivamente. Para o potencial antiviral, o extrato de butanol e o extrato de metanol apresentaram melhor título de hemaglutinação de $4 \mathrm{com}$ as cepas virais NDV e IBV, respectivamente. Conclui-se que o óleo do lagarto possui potencial antimicrobiano contra diferentes cepas de patógenos (vírus e bactérias).
\end{abstract}

Palavras-chave: Saara hardwickii, hemaglutinação, antibacteriano, antiviral, zona de inibição, zooterápico.

\section{Introduction}

The eastern spiny tailed lizard Saara hardwickii is found in Pakistan, India, and Afghanistan. The only herbivorous lizard species currently distributed in Cholistan and Thar Desert of Pakistan (Dias et al., 2013). Saara hardwickii has a dorso ventrally bedfast physique with blubbery spiny tailed whorls of annoying scales (Hashmi and Khan, 2014). The first traditional medicine made from spiny tailed lizard's parts and products in early 1990s was used for treatment of 20 critical illnesses such as diabetes, heart diseases, hypertension, gout, kidney problems and sexual dysfunction (Yuan et al., 2016). Reptiles are traded globally

for medicinal purposes especially lizards species including Moroccan worm lizard, Tangier worm lizard, and, possibly, Moroccan spiny lizard (Uromastyx nigriventris), all have medicinal uses (Nijman and Bergin, 2017).

Approximately $80 \%$ of the world's population depends on natural animal and/or plant-based medicines (Kioko et al., 2015). The lizards named Varanus niloticus, Varanus bengalensis body parts have been used to cure the diseases in China, Sudan and India. They have multiple medicinal uses and can be employed to treat more than one ailment. In Brazil products derived from Tupinambis merianae

*e-mail: maryamarshad616@gmail.com

Received: June 22, 2021 - Accepted: October 22, 2021

This is an Open Access article distributed under the terms of the Creative Commons Attribution License, which permits unrestricted use, distribution, and reproduction in any medium, provided the original work is properly cited. 
and Tupinambis teguixin, were used to treat different kind of skin allergies (Alves and Rosa, 2007). In India, various products derived from the Land monitor (Varanus bengalensis) are used to treat hemorrhoids, rheumatism, body pain and burns, as well as spider and snake bites (Kakati et al., 2006). Reptile's oil like that of snake's has also been used as traditional medicine for skin problems, local tissue necrosis and wound assessments. Cobra oil has been frequently used as a traditional cure of skin care. Boa constrictor oil has antimicrobial and anti-inflammatory activities (Khunsap et al., 2016). An extensively used zootherapeutic product obtained from body fat of Brazilian lizard (Tupinambis merianae). Such products are used for treatments of respiratory problems, throat infections, snake bites, asthma, tumors, inflammations, deafness and skin problems (Ferreira et al., 2010).

For the purpose of drug formation, epidemiology and prediction of therapeutic aspects, the testing methods are associated with antimicrobial sensitivity testing. The antimicrobial testing methods are used for in vitro analysis of extract and drugs to be included as essential antimicrobial agents (Balouiri et al., 2016). The present study was aimed to use the multi strains of bacteria and virus to evaluate the antimicrobial and antiviral abilities of lizard (Saara hardwickii) body oil.

\section{Methodology}

\subsection{Sample collection and extracts preparation:}

The fat sample was collected from the spiny tailed lizard (Saara hardwickii) from its ventral region (Ferreira et al., 2010). Animal was captured from Cholistan Desert of Punjab, Pakistan, and four different extracts of lizard's oil were prepared by using the solvents; n-hexane, butanol, ethyl acetate and methanol as described by (Dias et al., 2013).The oil was mixed with the four solvents to make the perfect extract named as n-hexane, butanol, ethyl acetate and methanol. Basically four extracts of lizard (Saara hardwickii) oil were prepared. The $1 \mathrm{ml}$ of oil mixed with $1 \mathrm{ml}$ of each solvent in the tube and vortex these tubes to mix up of these two solvents (Tanhaeian et al., 2020).

\subsection{Antiviral study}

\subsubsection{Cultivation of viruses' strains}

All the strains were freshly cultivated in embryonated eggs of 11 days chicken. In the $1^{\text {st }}$ trial, the HA titer was 0 . After $6^{\text {th }}$ trial, the titer was 2048.This activated viruses were subjected to In Ovo antiviral assay.

\subsubsection{Inoculation of poultry viruses in chicken embryonated eggs}

Eleven days old chicken embryonated eggs were taken from a local hatchery. The chorio-allantoic fluid of embryonated eggs were used to inoculated with the viruses. The eggs were candled before inoculations. The viral strains; NDV, H9N2 and IBV inoculated via chorioallantoic route. The blood were collected after $48-72$ hours and subjected further to further hemagglutination test (Danish et al., 2018)1.

\subsubsection{Hemagglutination Test (HA)}

Chicken blood was collected in freshly prepared Alsevior solution and centrifuged at 4000rpm for $5 \mathrm{~min}$. The supernatant was discarded and RBCs were washed with PBS (Phosphate buffered saline, pH 7.2). To prepare $1 \%$ suspension $10 \mu$ l packed RBCs were added into $1 \mathrm{ml}$ PBS (pH 7.4) solution. Future cells were used to perform the HA test (Danish et al., 2018)2. The antiviral effect is reported in the terms of HA titer, higher the HA titer value in the presence of oil extract, lower the antiviral effect (Akhtar et al., 2020)(Tavakoli et al., 2017).

Antiviral assay: The lizard oil extract were mixed with an equal volume of viral inoculums and injected in 11 days old chicken embryonated eggs as method described by (Rajbhandari et al., 2001). Filter sterilized water was used as negative control and viruses without any animal extracts were used in the case of virus control. The eggs were harvested 48 hours post-infection and HA were performed. All the protocols described in this study were approved from departmental biosafety committee of the Islamia University of Bahawalpur, Pakistan (Danish et al., 2018)2.

\subsection{Antibacterial study}

\subsubsection{Bacterial strains}

Four bacterial strains viz. Eschericia coli, Staphylococcus aureus, Proteus vulgaris and Pseudomonas aeruginosa were taken from Quaid e Azam medical college BWP Pakistan. Antibacterial activity on the above-mentioned bacterial species was determined and noted the zone of inhibition by disc diffusion method (Yaqeen et al., 2013).

\subsubsection{Media preparation}

Nutrient Broth: Nutrient broth was prepared by dissolving $1.3 \mathrm{~g}$ of it in $100 \mathrm{ml}$ of distilled water and sterilized in autoclave at $121^{\circ} \mathrm{C}$ for 1 hour (Hussain et al., 2015) ${ }^{1}$.

Nutrient agar: Nutrient agar was made by dissolving $2.8 \mathrm{~g}$ of it in distilled water and sterilized it in the autoclave at $121^{\circ} \mathrm{C}$ (Hussain et al., 2015) ${ }^{2}$.

\subsubsection{Disc diffusion assay for the determination of antibacterial activity:}

Agar plates were prepared. And antibacterial activity of the oils extracts was determined by disc diffusion method. The process is easy and feasible to check the antibacterial activity of many drugs at a time. Bacterial culture was grown in the nutrient broth media by inoculation of the strain from stock. After refreshing the culture different aliquots were made by dispensing in the sterile Eppendorf tubes (Cunha-Neto et al., 2020).

\subsection{Principle of disc diffusion method}

The disc of filter paper containing a drug or antibacterial compound is placed on the surface of agar plate containing a specific strain of bacteria against which the antibacterial 
activity is being checked. After the overnight incubation a clear zone of no growth (called zone of inhibition) is measured around the disc. The greater the zone the greater is the efficacy of drug or it is more lethal to the specific bacteria (Fernando et al., 2020)

\subsection{Micro dilution method}

Dilution susceptibility testing methods are used to determine the minimal concentration of antimicrobial needed to inhibit or kill the microorganism. This can be achieved by dilution of antimicrobial in either agar or broth media. Antimicrobials are tested in $\log 2$ serial dilutions (two fold).

The bacterial strains used were $S$. aureus, $P$. vulgaris, $P$. aeruginosa and E. coli, Antibacterial activity was measured by agar disk diffusion method. MIC of compounds having significant antibacterial potential was determined using broth dilution method (Jiang et al., 2013). The micro titer plates were incubated overnight at $37^{\circ} \mathrm{C}, \mathrm{p}$-iodonitrophenyltetrazolium violet ((INT) solution $(2 \mathrm{mg} / \mathrm{ml})$ was prepared. The MIC value indicates the lowest concentration of the extracts required to show bacteriostatic activity.

\section{Results}

\subsection{Antiviral activity against Newcastle Disease Virus $(N D V)$ :}

The antiviral potential of oil extracts prepared were tested against NDV virus was determined in term of hemagglutination test (HA). Two out of four extracts were found effective in controlling the growth of NDV (Figure 1). The butanol and methanol extracts were effective against viral activity with the HA titer of 04 (Figure 1 Lane 2\&4).
The ethyl acetate extract was found least effective than other three with the HA titer of 32(Figure 2 Lane 1).The virus control of NDV has showed HA titer of 2048 (Figure 2. Lane 5) (Table 1).

\subsection{Antiviral activity against Infectious Bronchitis Virus (IBV):}

Different fractions of Saara hardwickii (lizard) body oil were tested against IBV. The methanol oil extract was very effective in controlling the viral activity with the HA titer of 04.The antiviral activity of IBV strain has showed HA titer of 08 with n-hexane. The ethyl acetate showed least effective antiviral activity against IBV strain with titer 16. Figure 2, Lane 3).

\subsection{Antiviral activity against Avian Influenza virus (H9N2):}

One (n-hexane) out of four extracts was found effective in controlling the growth of H9N2 (Figure 3). Butanol and ethyl acetate were equally effective in controlling virus with HA titer of 32 (Figure 3 lane 1, lane 2) respectively. Higher HA titer was found in n-hexane with HA titer of 16 (Figure 3, Lane 2). The virus control has showed HA titer of 2048 (Figure 3.Lane 5) (Table 1).

\subsection{Antibacterial activity}

Antibacterial activity against four bacterial strains viz. Escherichia coli, Staphylococcus aureus, Proteus vulgaris and Pseudomonas aeruginosa were determined and the zone of inhibition was calculated by the disc diffusion method. The n-hexane oil extract was found best against E.coli bacterial strain with the zone of inhibition of $5 \mathrm{~mm}$ (Figure 4). Ethyl acetate oil extract showed the maximum zone of inhibition as $7 \mathrm{~mm}$ against Pseudomonas aeruginosa as compared to

\section{Antiviral activity of oil:}
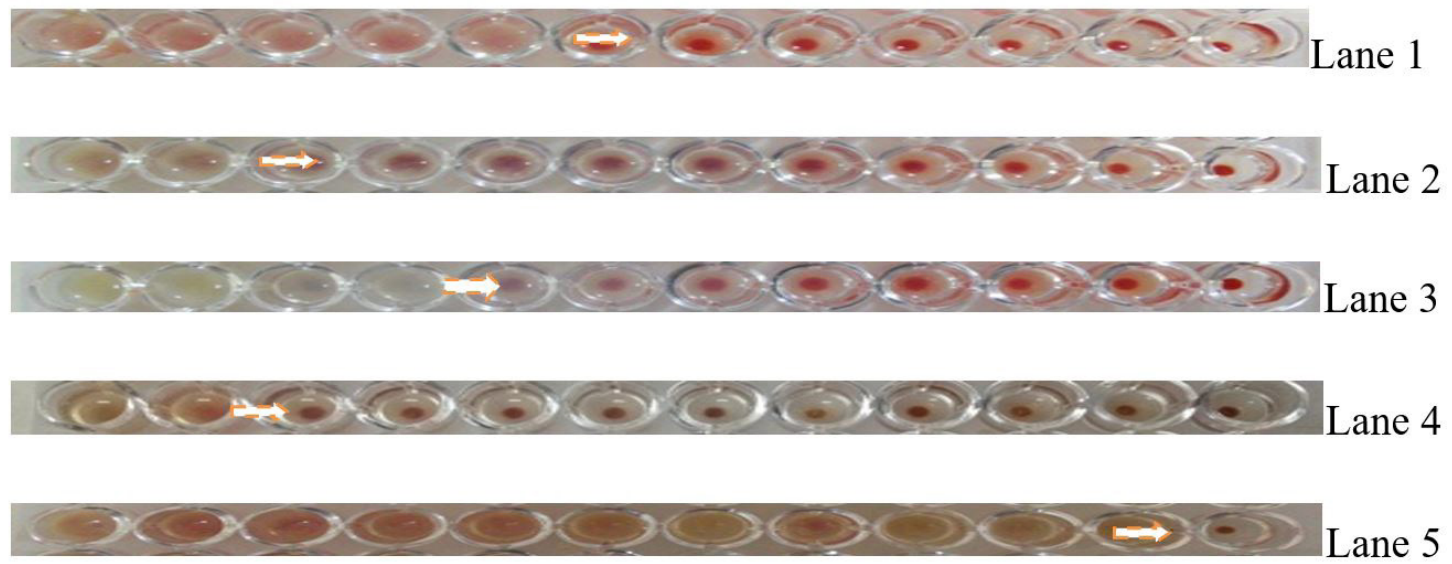

Figure 1. Anti NDV activities from different extracts of Lizard oil. Lane 1: HA titer of Ethyl acetate extract of lizard oil. Lane 2: HA titer of butanol extract of lizard oil. Lane 3: HA titer of n-hexane extract of lizard oil. Lane 4: HA titer of Methanol extract of lizard oil Lane 5: NDV as virus control. 

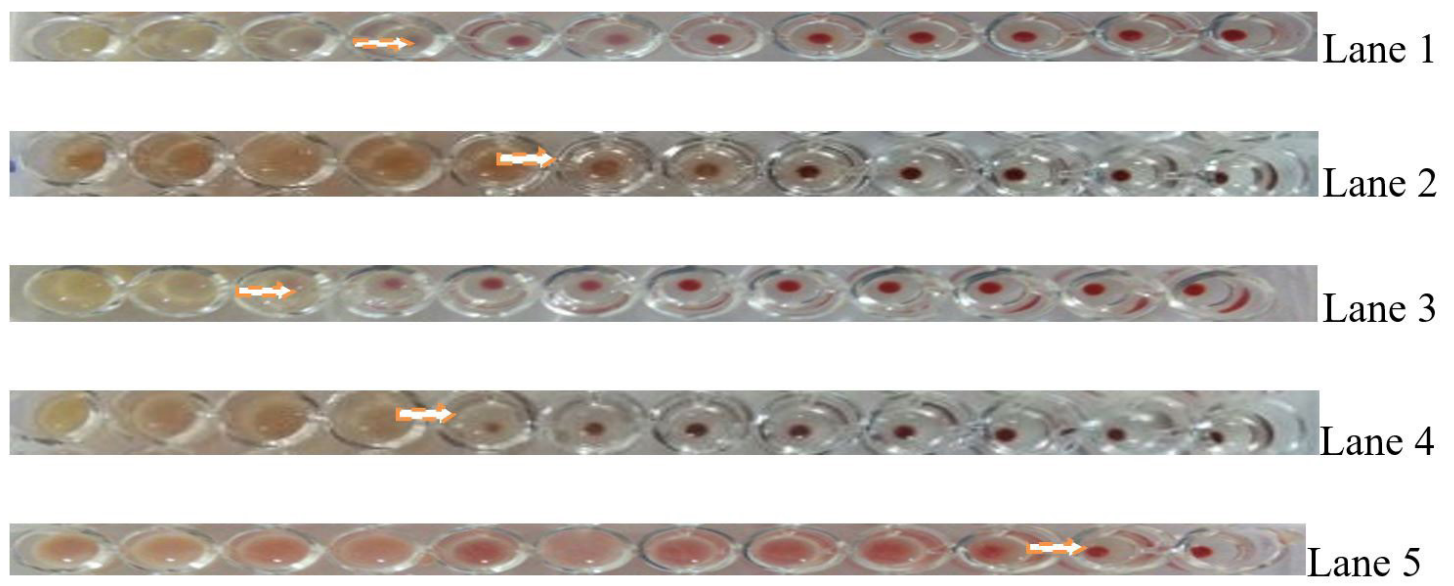

Figure 2. Anti IBV activities from different extracts of Lizard oil. Lane 1: HA titer of n-hexane extract of lizard oil. Lane 2: HA titer of butanol extract of lizard oil. Lane 3: HA titer of methanol extract of lizard oil. Lane 4: HA titer of Ethyl acetate extract of lizard oil Lane 5: IBV as virus control.
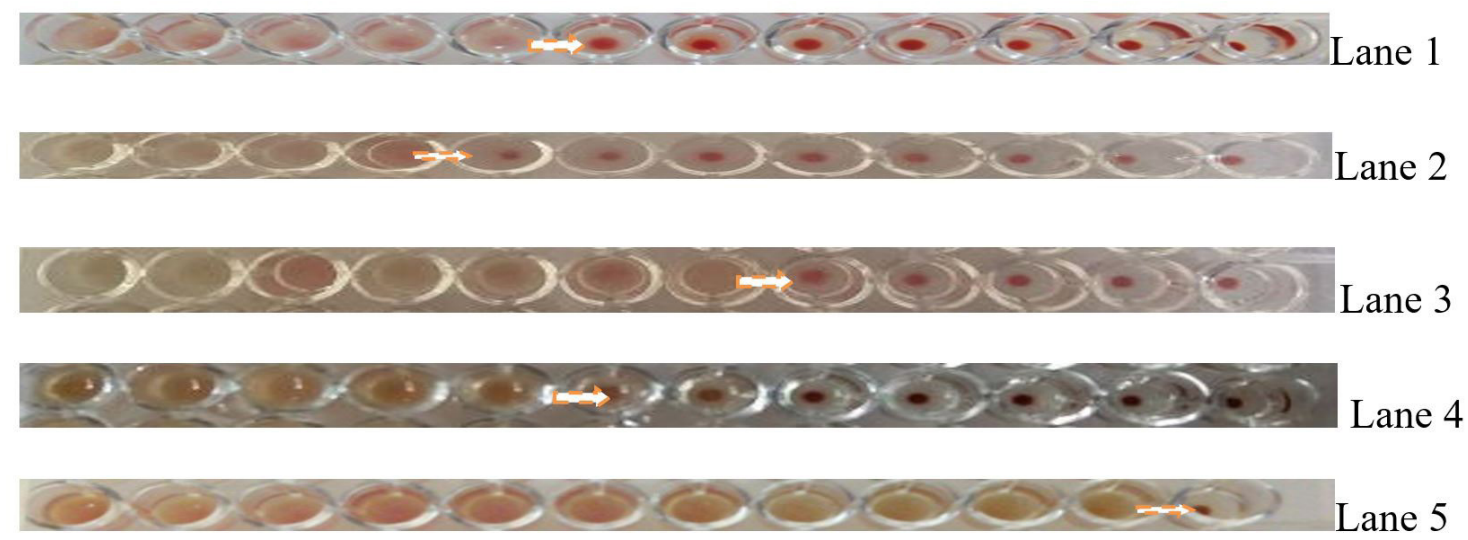

Figure 3. Anti H9N2 activities from different extracts of Lizard oil. Lane 1: HA titer of butanol extract of lizard oil. Lane 2: HA titer of n-hexane extract of lizard oil. Lane 3: HA titer of methanol extract of lizard oil. Lane 4: HA titer of Ethyl acetate extract of lizard oil Lane 5: H9N2 as virus control.

Antibacterial activity of oil:

Table 1. Antiviral activity results with different extracts and HA titer produced against three selected virus species.

\begin{tabular}{llcc}
\hline Virus & \multicolumn{1}{c}{$\begin{array}{c}\text { Fractions of oil } \\
\text { extracts }\end{array}$} & HA titer & Control virus \\
\hline \multirow{4}{*}{ NDV } & Ethyl acetate & 32 & 2048 \\
& Butanol & 4 & 2048 \\
& n-hexane & 16 & 2048 \\
& Methanol & 4 & 2048 \\
& Ethyl acetate & 16 & 2048 \\
& Butanol & 32 & 2048 \\
& n-hexane & 8 & 2048 \\
& Methanol & 4 & 2048 \\
& Ethyl acetate & 32 & 2048 \\
& Butanol & 32 & 2048 \\
& n-hexane & 16 & 2048 \\
& Methanol & 128 & 2048 \\
\hline
\end{tabular}

other strains (Figure 5). Our results indicate that butanol oil extract was only effective against Staphylococcus aureus with zone of inhibition of $7 \mathrm{~mm}$ (Figure 6). The methanol oil extract has shown no significant activity against any bacterial strain. The ethyl acetate oil extract showed the maximun zone of inhibition of $7 \mathrm{~mm}$ against Pseudomonas aeruginosa (Figure 5) and with Proteus vulgaris 6.25 zone of inhibition (Figure 7). The antibiotic drug, ampiciline was used as positive control which has shown significant zones of inhibition against all tested bacterial strains; E. coli, $P$. vulgaris, $P$. aeruginosa and $S$. aureus $5 \mathrm{~mm}, 11 \mathrm{~mm}, 10 \mathrm{~mm}$ and $9 \mathrm{~mm}$ respectively (Figure 4-7 'box named A') (Table 2).

\section{Discussion}

A large number of animal species are utilized for medicinal purposes throughout the world. In Brazil 345 animal species have been used for their medicinal 
values elaborating the importance of regional fauna for populations (Sales et al., 2015). According to WHO, still more than $80 \%$ of the world's population depend on traditional medicines obtained from natural sources (Arunkumar and
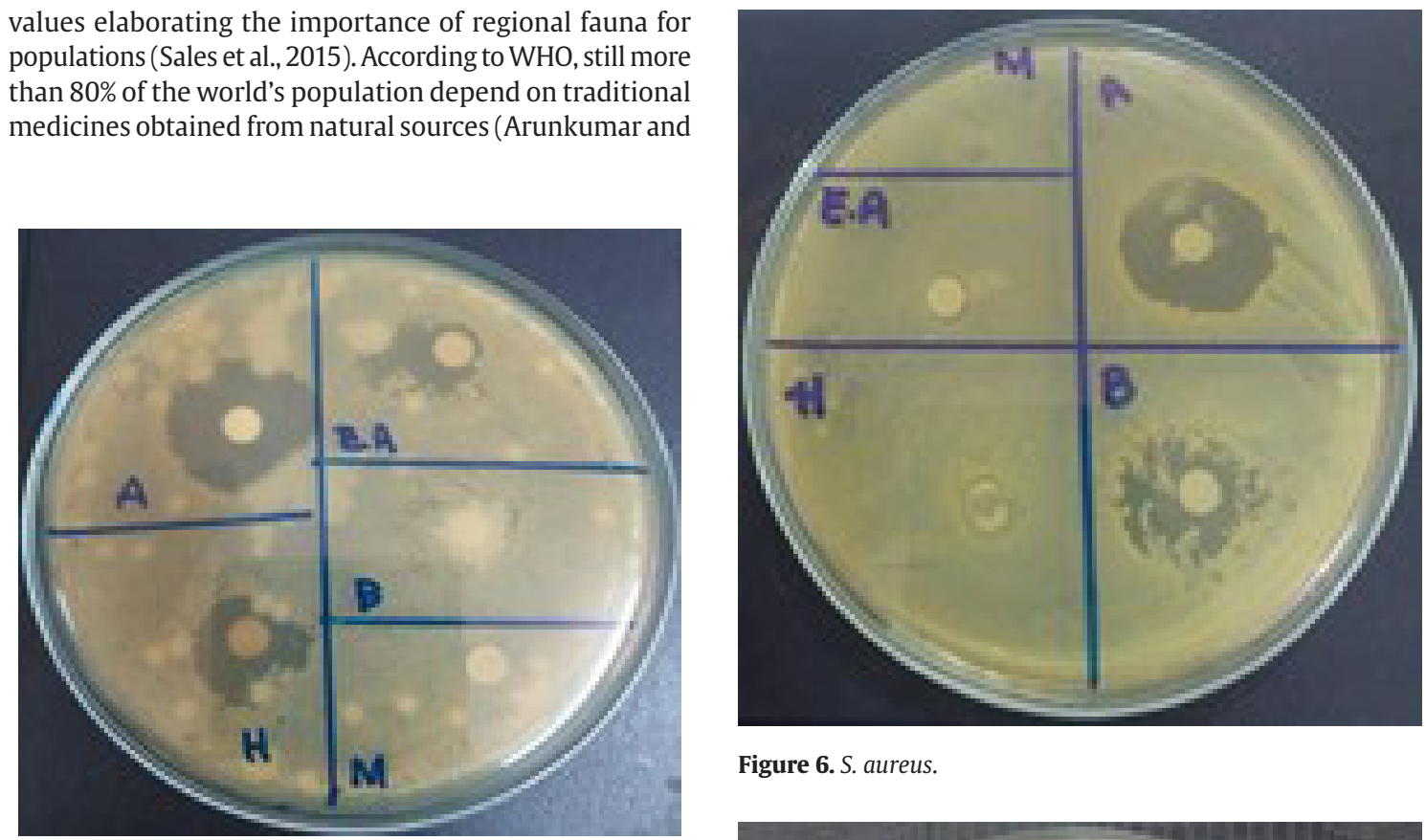

Figure 6. S. aureus.

Figure 4. E. coli.
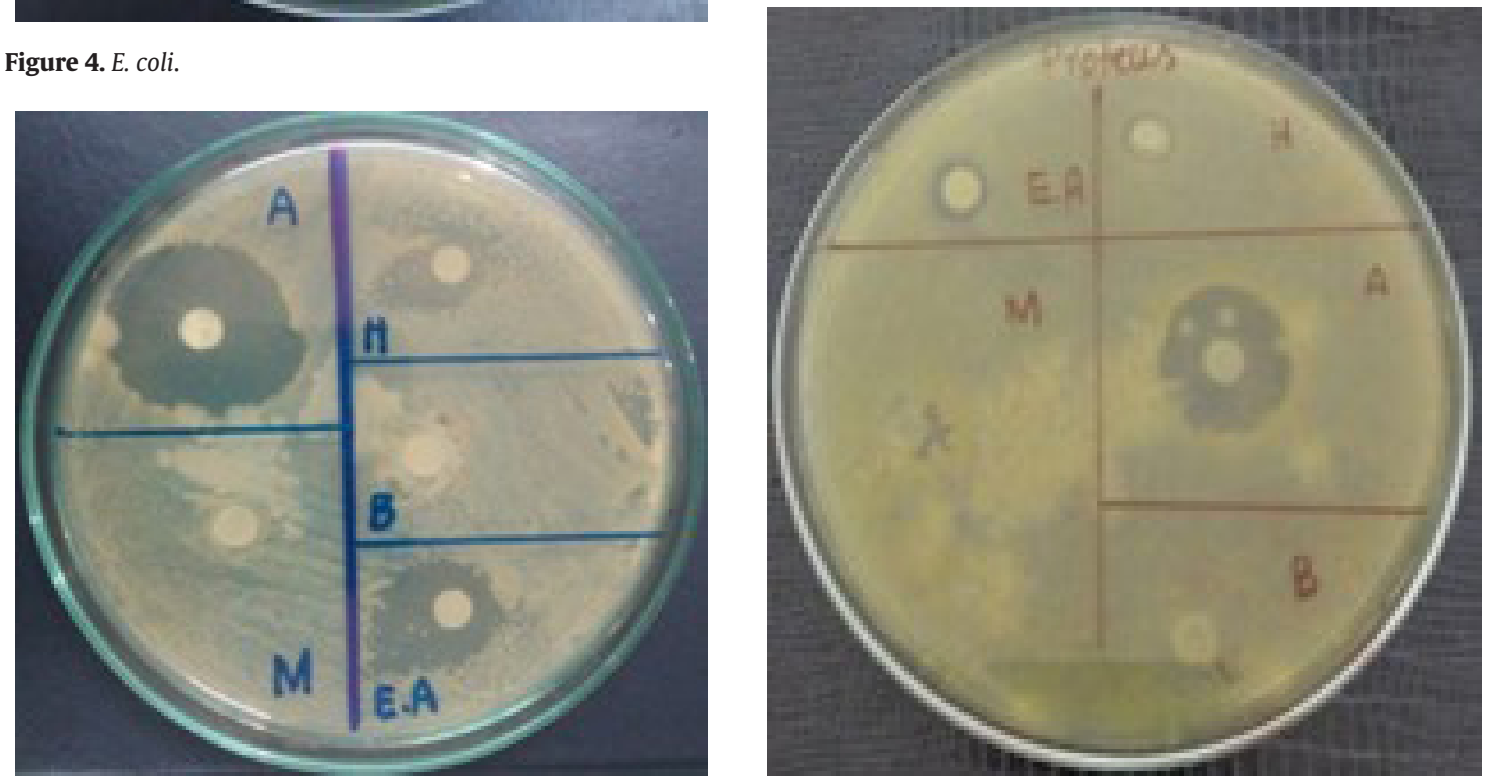

Figure 5. P. aeruginosa.

Figure 7. P. vulgaris.

Table 2. Antibacterial assay from lizard (Saara hardwicikii) Inhibition zone of various bacterial strains (in millimeters) against Lizard (Saara hardwickii) oil and MIC in microliters.

\begin{tabular}{|c|c|c|c|c|c|c|c|c|c|}
\hline \multirow{3}{*}{ Sr.no } & \multirow{3}{*}{ Solvent/Compoud } & \multirow{2}{*}{\multicolumn{2}{|c|}{$\begin{array}{l}\text { E. coli } \\
\mathrm{mm} / \mu \mathrm{I}\end{array}$}} & \multirow{2}{*}{\multicolumn{2}{|c|}{$\begin{array}{c}\text { P. aeruginosa } \\
\mathrm{mm} / \mu \mathrm{I}\end{array}$}} & \multirow{2}{*}{\multicolumn{2}{|c|}{$\begin{array}{c}\text { S. aurues } \\
\mathrm{mm} / \mu \mathrm{l}\end{array}$}} & \multirow{2}{*}{\multicolumn{2}{|c|}{$\begin{array}{c}\text { P. vulgaris } \\
\mathrm{mm} / \mu \mathrm{l}\end{array}$}} \\
\hline & & & & & & & & & \\
\hline & & ZOI & MIC & ZOI & MIC & ZOI & MIC & ZOI & MIC \\
\hline 1 & Butanol & 0 & 0 & 0 & 0 & 7 & 12.5 & 0 & 0 \\
\hline 2 & n-Hexane & 5 & 12.5 & 3 & 6.25 & 0 & 0 & 2 & 3 \\
\hline 3 & Methanol & 0 & 0 & 0 & 6.25 & 0 & 0 & 0 & 0 \\
\hline 4 & Ethyl acetate & 7 & 25 & 7 & 6.25 & 0 & 0 & 3 & 6.25 \\
\hline 5 & Ampicillin & 5 & 12.5 & 10 & 25 & 9 & 12.5 & 11 & 25 \\
\hline
\end{tabular}


Muthuselvam, 2009). The common use of the body fat of Tupinambis merianae is widely disseminated in many regions of Brazil against many microbes (Ferreira et al., 2009).

In the current study four different oil extracts were prepared and tested against four bacterial and three viral strains responsible to cause serious economic loses to poultry industry in Asia. Traditionally the spiny tailed lizard body oil was considered quite effective in controlling the poultry viruses' for in vitro conditions (Santos et al., 2012). The butanol and methanol oil extracts showed the significant activity against Newcastle Disease Virus (NDV) with HA titer of 04, higher the HA titer lower the antiviral activity. Similarly, the methanol extract showed remarkable antiviral activity against Infectious Bronchitis Virus (IBV) with HA titer of 04 . This trend of Reptilian oil effectiveness against viral infections in livestock was also observed by (Mahawar and Jaroli, 2008). The n-hexane oil extract was best to control Avian Influenza Virus (AIV) H9N2 with HA titer of 16 . The research work conducted by (Alves et al., 2007) on poultry virus showed that lizard body oil gives an outstanding remedy.

The antibacterial assay showed that ethyl acetate and n-hexane oil extracts were excellent in performance against Escherichia coli with $7 \mathrm{~mm}$ and $5 \mathrm{~mm}$ zone of inhibition and MIC $25 \mu \mathrm{l}$ and $12.5 \mu \mathrm{l}$ respectively. Similarly, the ethyl acetate showed best antibacterial assay against Pseudomonas aeruginosa with $7 \mathrm{~mm}$ zone of inhibition and MIC 6.25 $\mu$ l. According to (Cabral et al., 2013) few Amphibians and Reptilian body fat oil is significantly valuable in curing antibacterial activities, though the specific chemical constituent within this oil still needs identification. The butanolic oil extract produced a remarkable zone of inhibition $7 \mathrm{~mm}$ and MIC $12.5 \mu \mathrm{l}$ against Staphylococcus aureus. No type of oil extract showed significant antibacterial assay against Proteus vulgaris. Our results are directly related with the work conducted on body oil from Tupinambis merianae to check its effectiveness against bacterial infections. The body fat of Tupinambis merianae was used to extract the oil similar to the present case of Saara hardwickii body oil extracted from body fat. The Escherichia coli and Staphylococcus aureus strains have been used to check and calculate the antibacterial activity of lizard body oil. Our results are in agreement with the results produced by (Ferreira et al., 2009).

\section{Conclusion}

From the findings of present study it is proposed that the body oil of Saara hardwickii is effective against E. coli and $P$. aeruginosa bacterial strain in addition to having the significant antiviral potential against all the tested viral strains; NDV, H9N2 and IBV. By using this oil new traditional and folk medications can be proposed on the basis of antimicrobial values. And other animals fats having such antimicrobial values can be find by adopting such methods.

\section{Acknowledgements}

This research work was accomplished under the supervision of molecular lab of Veterinary College Islamia University Bahawalpur Pakistan.

\section{References}

AKHTAR, S., NAZAR, B. and SHARIQ, A., 2020. The comparison of sensitivity and specificity of ELISA-based microneutralization test with hemagglutination inhibition test to evaluate neutralizing antibody against Influenza Virus (H1N1). Journal of Medicine. Physiology and Biophysics, vol. 65, pp. 56-60.

ALVES, R.R. and ROSA, I.L., 2007. Zootherapy goes to town: the use of animal-based remedies in urban areas of ne and $n$ brazil. Journal of Ethnopharmacology, vol. 113, no. 3, pp. 541-555. http://dx.doi.org/10.1016/j.jep.2007.07.015. PMid:17719192.

ALVES, R.R., ROSA, I.L. and SANTANA, G.G., 2007. The role of animal-derived remedies as complementary medicine in Brazil. Bioscience, vol. 57, no. 11, pp. 949-955. http://dx.doi. org/10.1641/B571107.

ARUNKUMAR, S. and MUTHUSELVAM, M., 2009. Analysis of phytochemical constituents and antimicrobial activities of Aloe vera L. against clinical pathogens. World Journal of Agricultural Sciences, vol. 5, no. 5, pp. 572-576.

BALOUIRI, M., SADIKI, M. and IBNSOUDA, S.K., 2016. Methods for in vitro evaluating antimicrobial activity: a review. Journal of Pharmaceutical Analysis, vol. 6, no. 2, pp. 71-79. http://dx.doi. org/10.1016/j.jpha.2015.11.005. PMid:29403965.

CABRAL, M.E.S., DIAS, D.Q., SALES, D.L., OLIVEIRA, O.P., TELES, D.A., ARAUJO FILHO, J.A.A., SOUSA, J.G.G., COUTINHO, H.D.M., COSTA, J.G.M., KERNTOPF, M.R., ALVES, R.R.N. and ALMEIDA, W.O., 2013. Evaluations of the antimicrobial activities and chemical compositions of body fat from the amphibians Leptodactylus macrosternum Miranda-Ribeiro (1926) and Leptodactylus vastus Adolf Lutz (1930) in Northeastern Brazil. Evidence-Based Complementary and Alternative Medicine, vol. 2013, pp. 913671. http://dx.doi.org/10.1155/2013/913671. PMid:23710241.

CUNHA-NETO, A., CARVALHO, L.A., CASTRO, V.S., BARCELOS, F.G., CARVALHO, R.C.T., RODRIGUES, D.D.P. and FIGUEIREDO, E.E.D.S., 2020. Salmonella Anatum, S. Infantis and S. Schwarzengrund in Brazilian cheeses: occurrence and antibiotic resistance profiles. International Journal of Dairy Technology, vol. 73, no. 1, pp. 296300. http://dx.doi.org/10.1111/1471-0307.12636.

DANISH, M.T., ASLAM, H.M.M. and ZAHRA, E.D., 2018. The comparison of sensitivity and specificity of ELISA-based microneutralization test with hemagglutination inhibition test to evaluate neutralizing antibody against influenza virus (H1N1). Pakistan Journal of Medical \&' Health Sciences, vol. 12, pp. 1052-1054.

DIAS, D.Q., CABRAL, M.E.S., SALES, D.L., OLIVEIRA, O.P., ARAUJO FILHO, J.A.A., TELES, D.A., SOUSA, J.G.G., DOUGLAS COUTINHO, H.M., COSTA, J.G.M., KERNTOPF, M.R., ALVES, R.R.N. and ALMEIDA, W.O., 2013. Chemical composition and validation of the ethnopharmacological reported antimicrobial activity of the body fat of phrynops geoffroanus used in traditional medicine. Evidence-Based Complementary and Alternative Medicine, vol. 2013, pp. 715040. http://dx.doi.org/10.1155/2013/715040. PMid:24302969.

FERNANDO, S.A., PANG, S., MCKEW, G.L., PHAN, T., MERLINO, J., COOMBS, G.W. and GOTTLIEB, T., 2020. Evaluation of the Haemophilus influenzae EUCAST and CLSI disc diffusion methods to recognize aminopenicillin and amoxicillin/clavulanate 
resistance. The Journal of Antimicrobial Chemotherapy, vol. 75 , no. 9, pp. 2594-2598. http://dx.doi.org/10.1093/jac/dkaa229. PMid:32585694.

FERREIRA, F.S., BRITO, S.V., RIBEIRO, S.C., SARAIVA, A.A., ALMEIDA, W.O. and ALVES, R.R., 2009. Animal-based folk remedies sold in public markets in Crato and Juazeiro do Norte, Ceará, Brazil. BMC Complementary and Alternative Medicine, vol. 9, no. 1, pp. 17. http://dx.doi.org/10.1186/1472-6882-9-17. PMid:19493345.

FERREIRA, F.S., BRITO, S.V., SARAIVA, R.A., ARARUNA, M.K., MENEZES, I.R., COSTA, J.G., COUTINHO, H.D., ALMEIDA, W.O. and ALVES, R.R., 2010. Topical anti-inflammatory activity of body fat from the lizard tupinambis merianae. Journal of Ethnopharmacology, vol. 130, no. 3, pp. 514-520. http://dx.doi.org/10.1016/j. jep.2010.05.041. PMid:20669366.

HASHMI, M.U.A. and KHAN, M.Z., 2014. Studies on some aspects of burrows pattern of monitor lizard (V.bengalensis) in the Karachi and Hyderabad, Sindh, Pakistan. American Journal of Zoological Research, vol. 8, no. 2, pp. 153-158.

HUSSAIN, T., FATIMA, I., RAFAY, M., SHAHZAD, M.I., ABDULLAH, M., BANO, S., AKHTAR, S. and RUBY, T., 2015. Comparison of antibacterial potential from leaves and fruits of different herbs and shrubs of family Solanaceae. International Journal of Agriculture and Biology, vol. 17, no. 6, pp. 1249-1254. http:// dx.doi.org/10.17957/IJAB/15.0039.

JIANG, L., WANG, F., HAN, F., PRINYAWIWATKUL, W., NO, H.K. and GE, B., 2013. Evaluation of diffusion and dilution methods to determine the antimicrobial activity of water-soluble chitosan derivatives. Journal of Applied Microbiology, vol. 114, no. 4, pp. 956-963. http://dx.doi.org/10.1111/jam.12111. PMid:23279192.

KAKATI, L.N., AO, B. and DOULO, V., 2006. Indigenous knowledge of zootherapeutic use of vertebrate origin by the Ao tribe of Nagaland. Journal of Human Ecology, vol. 19, no. 3, pp. 163-167. http://dx.doi.org/10.1080/09709274.2006.11905874.

KHUNSAP, S., VESARATCHAPONG, T., LAONGBAO, P., CHANHOME, L., BURANAPRADITKUN, S., PAKMANEE, N. and BOONCHANG, S., 2016. Antioxidant, anticancer cell lines and physiochemical evaluation of cobra oil. Int J Pure App Biosci, vol. 4, no. 3, pp. 21-27. http://dx.doi.org/10.18782/2320-7051.2296.

KIOKO, J., BAKER, J., SHANNON, A. and KIFFNER, C., 2015. Ethnoecological knowledge of ticks and treatment of tick-borne diseases among maasai people in northern tanzania. Veterinary World, vol. 8, no. 6, pp. 755-762. http://dx.doi.org/10.14202/ vetworld.2015.755-762. PMid:27065643.

MAHAWAR, M.M. and JAROLI, D.P., 2008. Traditional zootherapeutic studies in India: a review. Journal of Ethnobiology and
Ethnomedicine, vol. 4, no. 1, pp. 17. http://dx.doi.org/10.1186/17464269-4-17. PMid:18634551.

NIJMAN, V. and BERGIN, D., 2017. Reptiles traded in markets for medicinal purposes in contemporary Morocco. Contributions to Zoology, vol. 86, no. 1, pp. 39-50. http://dx.doi. org/10.1163/18759866-08601003.

RAJBHANDARI, M., WEGNER, U., JULICH, M., SCHOPKE, T. and MENTEL, R., 2001. Screening of Nepalese medicinal plants for antiviral activity. Journal of Ethnopharmacology, vol. 74, no. 3, pp. 251-255.

SALES, D.L., OLIVEIRA, O.P., CABRAL, M.E.S., DIAS, D.Q., KERNTOPF, M.R., COUTINHO, H.D.M., COSTA, J.G., FREITAS, F.R., FERREIRA, F.S., ALVES, R.R. and ALMEIDA, W.O., 2015. Chemical identification and evaluation of the antimicrobial activity of fixed oil extracted from Rhinella jimi. Pharmaceutical Biology, vol. 53, no. 1, pp. 98-103. http://dx.doi.org/10.3109/13880209.2014.911331. PMid:25289527.

SANTOS, I.J., MATIAS, E.F., SANTOS, K.K., BRAGA, M.F., ANDRADE, J.C., SOUZA, T.M., SANTOS, F.A., SOUSA, A.C.A., COSTA, J.G. and MENEZES, I.R., 2012. Evaluation of the antimicrobial activity of the decoction of Tropidurus hispidus (Spix, 1825) and Tropidurus semitaeniatus (Spix, 1825) used by the Traditional Medicine. Evidence-Based Complementary and Alternative Medicine, vol. 2012, pp. 747969. PMid:21754948.

TANHAEIAN, A., SEKHAVATI, M.H. and MOGHADDAM, M., 2020. Antimicrobial activity of some plant essential oils and an antimicrobial-peptide against some clinically isolated pathogens. Chem Biol Technol Agric, vol. 7, no. 1, pp. 13. http://dx.doi. org/10.1186/s40538-020-00181-9.

TAVAKOLI, A., REZAEI, F., NASAB, G.S.F., ADJAMINEZHAD-FARD, F., NOROOZBABAEI, Z. and MOKHTARI-AZAD, T., 2017. The comparison of sensitivity and specificity of ELISA-based microneutralization test with hemagglutination inhibition test to evaluate neutralizing antibody against influenza virus (H1N1). Iranian Journal of Public Health, vol. 46, no. 12, pp. 1690-1696. PMid:29259944.

YUAN, H., MA, Q., YE, L. and PIAO, G., 2016. The traditional medicine and modern medicine from natural products. Molecules, vol. 21, no. 5, pp. 559. http://dx.doi.org/10.3390/molecules21050559. PMid:27136524.

YAQEEN, Z., NAQVI, N. U. H., SOHAIL, T., FATIMA, N., and IMRAN, H., 2013. Screening of solvent dependent antibacterial activity of Prunus domestica. Pakistan Journal of Pharmaceutical Sciences, vol. 26, no. 2, pp. 409-414. 